\title{
The effect of pasteurized milk and pure soy milk on enamel remineralization
}

\author{
Annesha Metly ${ }^{1}$, Dedi Sumantri ${ }^{1 *}$, Fadil Oenzi ${ }^{2}$ \\ ${ }^{1}$ Department of Prosthodontics and Dental Biomaterial, Faculty of Dentistry Andalas University, \\ Indonesia \\ 2Postgraduate Department of Biomedical, Faculty of Medicine Andalas University, Indonesia
}

\begin{abstract}
Introduction: Tooth remineralization agent can be found in pasteurized milk and soy milk. $\mathrm{Ca}^{2+}$ and $\mathrm{PO}_{4}^{3-}$ ions concentration in both products inhibited hydroxyapatite dissolution and enhanced remineralization. This study was aimed to investigate the effect of pasteurized milk and pure soy milk on tooth enamel remineralization. Methods: This study was an experimental laboratory with pre-test post-test control group design. Twenty-seven maxillary premolars were divided into 3 groups; 37\% phosphoric acid used to demineralized the samples followed by initial enamel hardness measurement. All samples were immersed in aquadest, pasteurized milk, and pure soy milk for 14 days, 102 minutes per day. Final enamel hardness was measured with the Vickers hardness test. Results: Increasing enamel hardness was found in all groups. Two-way ANOVA test was used to compare the increase of enamel hardness in all group, which showed the $p$-value $=0.002$. Post-hoc LSD test was then used to compare the increase of the enamel hardness in pasteurized milk and pure soy milk groups, which resulted in the $p$-value $=0.147$. Conclusion: There was an effect of pasteurized milk and pure soy milk group on enamel remineralization. However, there was no difference in the increase of enamel hardness value between pasteurized milk and pure soy milk groups.
\end{abstract}

Keywords: Pasteurized milk, pure soy milk, tooth enamel, remineralization.

p-ISSN: 1979-0201, e-ISSN: 2549-6212; Available from: http://jurnal.unpad.ac.id/pid/article/view/22833

DOI: 10.24198/pjd.vol31no3.22833

Submission: Jul 13, 2019; Accepted: Nov 20, 2019; Published online: Nov 30, 2019

\section{INTRODUCTION}

There is an interdependent relationship between nutrition and health of oral tissues. Eating a wellbalanced diet is imperative to maintaining good oral health. ${ }^{1}$ Dietary habit plays a vital role in preventing oral diseases, including dental caries, dental erosion, developmental diseases, oral mucose disease, and periodontal disease. Food that contained high calcium and phosphate could enhance tooth remineralization. ${ }^{2-3}$ The tooth is composed of enamel, pulp-dentine complex, and cementum. Enamel is the hardest substance in the human body and serves as the wear-resistant outer layer of the dental crown. Enamel consists of about $65 \%$ water, $20 \%$ organic material and $15 \%$ hydroxyapatite. Hydroxyapatite comprises calcium and phosphate predominantly. ${ }^{4-5}$ 
Teeth are exposed to food, drink, and oral microbiota; therefore, they have developed a high resistance to localized demineralization. Demineralization is the process of minerals ions removals from HA crystals of hard tissues, for example, enamel, dentin, cementum, and bone. Restoring these mineral ions to the HA crystals is called remineralization. Both processes occur on the tooth surface. Demineralization and remineralization are a dynamic physicochemical process that impact hardness and enamel strength. ${ }^{6-10}$ Remineralization is the redeposition process of enamel's mineral, which occurs in the normal salivary $\mathrm{pH}$. There are some ideal requirements of remineralization material; having low viscosity to diffuses into the subsurface or delivers calcium and phosphate into the subsurface. Stabilized bioavailability of calcium, phosphate, and fluoride ions do not create an excess of calcium; thus also do not favour the calculus formation. It also works at an acidic $\mathrm{pH}$, in xerostomic patients, and boosts the remineralization properties of saliva. ${ }^{7-10}$ Milk provides large amounts of calcium and phosphates and helps tooth remineralization. ${ }^{7}$ Pasteurized milk is a product that processed with heat exposure in the temperature of $62.8^{\circ} \mathrm{C}$ or $71.7^{\circ} \mathrm{C}$, and the most kind of milk consumed by society. ${ }^{3,11}$ The low viscosity of milk facilitates calcium ion and phosphate diffusion in enamel that leads to remineralization process. ${ }^{12}$ Fresh milk, pasteurized milk, and skimmed milk were effective in reducing enamel dissolution. Gunn and Woodward ${ }^{3}$ reported a higher effectivity of pasteurized milk in enamel dissolution prevention than breast milk in vitro. Rahardjo et al ${ }^{13}$ showed a higher protective effect against demineralization in the topical application of milk than a combined form of milk-tea and $0.2 \%$ milk-NaF. ${ }^{13}$

Calcium, phosphate, and casein in milk inhibited demineralization and enhanced tooth remineralization. Casein derivates, such as casein phosphopeptide (CPP) is an alternative remineralizing agent due to its ability to stabilize the calcium and phosphate in the amorphous noncrystalline state, also known as amorphous calcium phosphate (ACP). CPP-ACP facilitates adhesion of calcium and phosphate into enamel microporosity, thus enhanced remineralization. ${ }^{9,14}$ Nowadays, increasing awareness of cows milk protein allergy and intolerance, and higher preference for vegan dietary habits have influenced people to choose cows milk substitutes. The alternative product that contained similar nutrition to cows milk is soy milk, coconut milk, and almond milk. ${ }^{15,16}$ Soybean has chosen as the main material of milk due to its high nutrition compared than other nut product. ${ }^{17}$ The use of soy milk was first reported about 2000 years ago in China. Soy milk was the first plantbased milk which served the purpose of providing nutrients to a population where the cow's milk supply was inadequate. ${ }^{18,19}$ Soy beverage contains much lower carbohydrates and fats compared to cow milk. Calcium and phosphor were the main mineral contained in soy milk and has an essential role in tooth and bone remineralization process. ${ }^{12,13}$

In previous research conducted by Widyaningtyas ${ }^{12}$ discovered a decreasing of enamel micropores depth in the teeth im-mersed with pure soy milk compared to artificial saliva as media for 8 hours in 14 days. High concentrated calcium and phos-phate, and low viscosity of soy milk accelerate precipitation of mineral calcium and phosphate thus lead to the enamel mi-croporosity closure happened and increased remineralization potential. This study showed that pure soy milk had a similarity to the remineralizing solution. ${ }^{12}$ Based on the explanation above, the present study was aimed to investigate the effect of pasteurized milk and pure soy milk in remineralizing enamel.

\section{METHODS}

This study was an experimental laboratory with pre-test post-test control group design. Inclusion criteria were as follows: post extraction premolars with normal size, shape, and intact crown. Exclusion criteria were decayed or fractured tooth, attrition, abrasion, erode tooth, dental filling, tooth with endodontic treatment, discoloured and cracked tooth. Samples were as many as 27 post-extraction premolars that met the inclusion and exclusion criteria.

Samples were cleaned and disinfected with alcohol, then rinsed by aquadest. The tooth was thoroughly cut at the cemento-enamel junction that subsequently separates the crown and the root part - tooth crown embedded in an acrylic mould with the mesial side facing upward. Samples were then divided into 3 groups, 9 samples each 
and numbered. The etchings were applied for 60 $\mathrm{s}$, rinsed by aquadest and dried. Initial enamel hardness measurement was performed using Vickers Hardness Tester.

All samples were immersed in artificial saliva for $24 \mathrm{~h}$, afterwards, immersed in aquadest, pasteurized milk, and pure soy milk that had been mixed with artificial saliva, each group in the temperature of $37^{\circ} \mathrm{C}$. Immersion duration depends on the average time of consuming a soft drink, which is $20 \mathrm{~s}$ - one-year consumption of approximately 25 hours. Remineralization time was 14 days and held for 102 minutes per day in 14 days. The samples enamel hardness was measured by the Vickers hardness test and collected as final data, and statistically analysed with a paired t-test to analyse the mean differences among all groups, followed with two-way ANOVA test.

\section{RESULTS}

Kolmogorov-Smirnov normality test was conducted before the statistical analysis, which resulted in $p>0.05$, indicated that data were normally distributed. Paired t-test was used to compare the enamel hardness value before and after immersion. There was significant differences in the enamel hardness value before and after immersion in pasteurized milk group and soy milk group $(\mathrm{p}<0.05)$, as presented in Table 1.

Table1. Enamel hardness before and after immersion In aquadest, pasteurized milk, and pure soy milk

\begin{tabular}{|c|c|c|c|c|c|c|}
\hline & \multicolumn{2}{|c|}{ Aquadest } & \multicolumn{2}{|c|}{ Pasteurized milk } & \multicolumn{2}{|c|}{ Pure soy milk } \\
\hline & Pre-test & Post-test & Pre-test & Post-test & Pre-test & Post-test \\
\hline$N$ & \multicolumn{2}{|c|}{9} & \multicolumn{2}{|c|}{9} & \multicolumn{2}{|c|}{9} \\
\hline Mean & 324.2 & 332.8 & 308.6 & 388.5 & 315.5 & 368.3 \\
\hline$\pm \mathrm{SD}$ & 33.63 & 24.73 & 30.60 & 27.18 & 24.21 & 20.03 \\
\hline $\mathrm{p}$-value & \multicolumn{2}{|c|}{0.355} & \multicolumn{2}{|c|}{0.001} & \multicolumn{2}{|c|}{0.002} \\
\hline
\end{tabular}

Two-way ANOVA test was used to compare the increasing value of enamel hardness from three groups. Data presented in Table 2 showed that there were significant differences in the increased enamel hardness value of all groups, with $\mathrm{p}=0.002$.
Post-hoc LSD was used to compare the increasing value of enamel hardness between pasteurized milk group and aquadest group, pure soy milk group and aquadest group, and pasteurized milk group and pure soy milk group. The test results showed the increasing value.

Table 2. Two Way Anova Results Of Increased Value Of Enamel Hardness Comparison In All Groups

\begin{tabular}{cccc} 
& N & Mean of increased enamel hardness value \pm SD & P-value \\
\hline Aquadest & 9 & $8.62 \pm 8.9$ & 0.002 \\
Pasteurized Milk & 9 & $79.96 \pm 3.42$ & \\
Pure Soy Milk & 9 & $52.87 \pm 8.42$ & \\
\hline
\end{tabular}

Figure 1. Mean of enamel hardness in post and pre-test

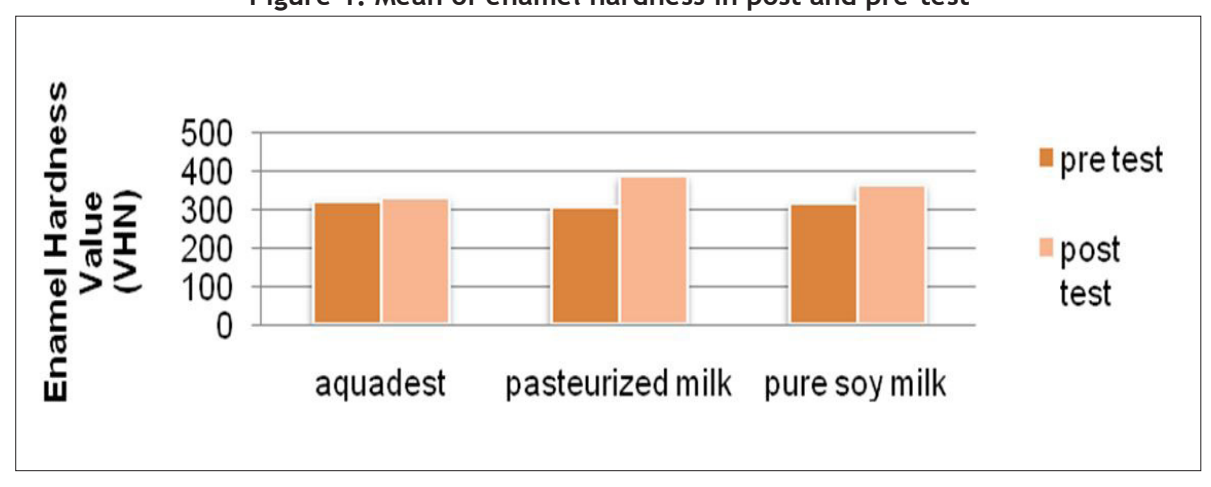




\begin{tabular}{lccc}
\hline & \multicolumn{3}{c}{ Table 3. Post-hoc LSD results } \\
\hline & N & Mean of increased enamel hardness value \pm SD & P-value \\
\hline Pasteurized Milk & 9 & $79.96 \pm 3.42$ & 0.001 \\
Aquadest & 9 & $8.62 \pm 8.9$ & 0.022 \\
Pure Soy Milk & 9 & $52.87 \pm 8.42$ & $8.62 \pm 8.9$ \\
Aquadest & 9 & $79.96 \pm 3.42$ & 0.147 \\
Pasteurized Milk & 9 & $52.87 \pm 8.42$ & \\
Pure Soy Milk & 9 & &
\end{tabular}

Table 3 presents that there were significant differences between increased enamel hardness value in pasteurized milk and aquadest group, with $p=0.001$. Pure soy milk and aquadest group showed a similar result with $p=0.022$. Pasteurized milk and soy milk showed no significant differences in increased enamel hardness value, with $p=$ 0.147 .

\section{DISCUSSION}

The results of this study indicated that there was a significant difference in the hardness value before and after being treated, based on paired t-test. This result showed that there was a significant increase of the tooth enamel hardness value after immersed in pasteurized milk and pure soy milk, with value $p=0.001$ and $p=0.002$. Increased value of enamel hardness in pasteurized milk group is caused by remineralization agents contained in milk, such as casein phosphopeptide, calcium, and phosphate.

Precipitation of calcium and phosphate ions will lead to the rebuilding of hydroxyapatite. ${ }^{14}$ The process of remineralization by soy milk depends on the diffusion of calcium and phosphate ions by utilising the low viscosity of the solution. Continuous diffusion caused calcium and phosphate ions to fill the enamel microporosity. ${ }^{12}$ Based on the two-way ANOVA test results, the increasing value of tooth enamel hardness was obtained the $p=0.002$. The results showed that there was a significant difference in the increasing hardness of tooth enamel in all three groups. This result suggested that pasteurized milk, pure soy milk, and aquadest affect the tooth enamel remineralization.

The post-hoc LSD test was performed to determine the difference of the increasing value of tooth enamel hardness between the group of pasteurized milk with aquadest and obtained the $p$-value $=0.001$. The results of this study indicated that there was a significant difference in the value of enamel hardness of pasteurized milk group when compared to aquadest control group. This study was similar to previous research conducted by Mettu et $\mathrm{al}^{20}$ which showed that casein phosphopeptide-amorphous calcium phosphate (CPP-ACP) in cow milk is increasing the enamel hardness more significantly when compared with aquadest and artificial saliva. ${ }^{20}$ The results showed that there was a significant difference from the increase of tooth enamel hardness value of pure soy milk group compared to aquadest control group with $\mathrm{p}$-value $=0.022$. This study was consistent with previous research conducted by Vongsavan et $\mathrm{al}^{21}$ stated that there is a difference from the increase in the value of enamel hardness immersed in the soy milk group with the control group. ${ }^{21}$ Remineralization triggered by the content of calcium and phosphate on soy milk. Based on the previous study, a glass of soy milk ( $245 \mathrm{~g})$ provides $9.8 \mathrm{mg}$ calcium and 120 $\mathrm{mg}$ phosphate. The immersion in soy milk would decrease demineralized enamel microporosity. It caused by calcium and phosphate ions diffuse into enamel pores and increasing hydroxyapatite saturation. ${ }^{12,22}$

The results showed that the comparison of increased hardness value between the pasteurized milk group and pure soy milk had the p-value of 0.147 , thus not significant. Although the content of calcium and phosphate ions in pasteurized milk was higher when compared to soy milk, the increase in enamel hardness in the cow milk group did not differ significantly from the soybean milk group. This result is due to the diffusion of calcium and phosphate ions for enamel remineralization 
in pasteurized milk is limited as most calcium, phosphate, and casein ions bind to the casein micelles or batches of casein in pasteurized milk. The binding of most calcium and phosphate ions in the casein micelles results in reduced quantity and bioavailability of calcium and phosphate ions for diffusion thus limiting the potential for remineralization of pasteurized milk. Soy milk contains no casein protein so that the diffusion of calcium and phosphate ions in enamel is not affected by milk protein bonds. ${ }^{21}$

The process of remineralization by pasteurized milk also depends on the natural casein phosphopeptides (CPP) content that forms the reservoir for the entry of calcium and phosphate ions into the enamel microporosity. Although pasteurized milk has natural CPP as a remineralization agent, casein phosphopeptideamorphous calcium phosphate (CPP-ACP) is the composition that increases the effectivity in enhancing remineralization.

A previous study conducted by Walker et $\mathrm{a}^{22}$ showed that there was a significant difference in remineralization rates from the sample groups who drank cow milk with an additional artificial CPPACP compared to the sample group who drank pure cow milk. This condition was caused by artificial CPP-ACP addition as much as 2.0 to 5.0 grams in cow milk which increased the number of minerals by $70-148 \%$. An increase in the number of minerals will lead to an increase in remineralization. The study showed that the effect of CPP levels on pasteurized milk on remineralization was not as significant as the effect of arti-ficial CPP-ACP.9,20

\section{CONCLUSION}

There is an effect of pasteurized milk and soy milk in remineralizing tooth enamel based on the increase of enamel hardness value. However, there is no significant difference between pasteurized milk and soy milk in raising the enamel hardness.

\section{REFERENCES}

1. lacopino $\mathbf{A M}$. Maintaining oral health in the aging population: the importance of the periodontal-systemic connection in the elderly. Grand Rounds Oral Sys Med. 2006; 1(3): 25-37.
2. Moynihan PJ. The role of diet and nutrition in the etiology and prevention of oral diseases. Bull World Health Organ. 2005; 83(9): 694-9.

3. Johansson I, Lif Holgerson P. Milk and Oral Health. Nestle Nutr Workshop Ser Pediatr Program. 2011; 67: 55-66. DOI: 10.1159/000325575

4. Avery JK, Chiego DJ (ed). Essentials of Oral Histology and Embryology. $3^{\text {rd }}$ ed. St. Louis: Mosby-Elsevier; 2006; p. 241.

5. Fejerskov O, Kidd E. Dental Caries: The Disease and Its Clinical Management. $2^{\text {nd }}$ ed. Hoboken: John Wiley \& Sons, Inc; 2009.

6. Cuy JL, Mann AB, Livi KJ, Teaford MF, Weihs TP. Nanoindentation Mapping of The Mechanical Properties of Human Molar Tooth Enamel. Arch Oral Biol. 2002; 47(4): 281-91. DOI: 10.1016/ s0003-9969(02)00006-7

7. Prasetyo EA. Acidity of soft drink decrease the surface hardness of tooth. Den J (Maj Ked Gi). 2005; 38(2): 60-3. DOI: 10.20473/j.djmkg. v38.i2.p60-63

8. Ferreira RI, Haiter-Neto F, Tabchoury CPM, Bóscolo FN. In vitro induction of enamel subsurface demineralization for evaluation of diagnostic imaging methods. J Appl Oral Sci. 2007; 15(5): 392-8. DOI: 10.1590/s167877572007000500004

9. Andini RF. Mikrostruktur Gigi Bovine setelah Perendaman dalam Ekstrak Teh Hijau dan Casein Phosphopeptide-Amorphous Calcium Phosphate (Penelitian Deskriptif Observasional) [minor thesis]. Surabaya: Airlangga University; 2013.

10. Shetty S, Hegde MN, Bopanna TP. Enamel Remineralization Assessment with Three Different Remineralizing Agents using Surface Microhardness: An In Vitro Study. J Conserv Dent. 2014; 17(1): 49-52. DOI: 10.4103/09720707.124136

11. Ambarsari I, Qanytah, Sudaryono T. Perubahan Kualitas Susu Pasteurisasi dalam berbagai Jenis Kemasan. J Penelit Pengembang Pertan. 2013; 32(1): 10-9.

12. Widyaningtyas V, Rahayu YC, Barid I. The Analysis of Enamel Remineralization Increase in Pure Soy Milk (Glycine max (L.) Merill. J Pust Kes. 2014; 2(2): 258-62.

13. Rahardjo A, Sahertain RD, Ramadhani SA, Maharani DA, Latief FDE. The Effect of Milk 
and It's Combination with Tea and 0,2\% Naf on Dental Enamel Remineralization Analyzed by Micro Computed Tomografy. J Dent Ind. 2014; 21(2): 53-6. DOI: 10.14693/jdi.v21i2.223

14. Azarpazhooh A, Limeback H. Clinical efficacy of casein derivatives: a systematic review of the literature. J Am Dent Assoc. 2008;139(7): 91524. DOI: $10.14219 /$ jada.archive.2008.0278

15. Claeys WL. Verraes C, Cardoen S, De Block J, Huyghebaert A, Raes $\mathrm{K}$, et al. Consumption of raw or heated milk from different species: An evaluation of the nutritional and potential health benefits. Food Cont. 2014; 42: 188-201. DOI: $10.1016 /$ j.foodcont.2014.01.045

16. Claeys WL. Verraes C, Cardoen S, De Block J, Huyghebaert A, Raes K, et al. Consumption of raw or heated milk from different species: An evaluation of the nutritional and potential health benefits. Food Cont. 2014; 42: 188-201. DOI: $10.1016 / j$. foodcont.2014.01.045

17. Sethi S, Tyagi SK, Anurag RK. Plant-based milk alternatives an emerging segment of functional beverages: A review. J. Food Sci Technol. 2016; 53(9): 3408-23. DOI: $10.1007 /$ s13197-016-2328-3

18. Budimarwanti C. Komposisi dan Nutrisi pada Susu Kedelai [thesis]. Yogyakarta: Yogyakarta
State University; 2007.

19. von Fraunhofer JA, Rogers MM. Dissolution of Dental Enamel in Soft Drink. Gen Dent. 2004; 52(4): 308-12.

20. Mettu S, Srinivas N, Reddy Sampath CH, Srinivas N. Effect of Casein Phosphopeptide Amorphous Calcium Phosphate (CPP ACP) on Caries-Like Lesions in Terms of Time and Nano- Hardness: an In Vitro Study. J Indian Soc Pedod Prev Dent. 2015; 33(4): 269-73. DOI: 10.4103/0970-4388.165657

21. Vongsavan K, Surarit R, Rirattanapong P. Effectiveness of soy milk with calcium on bovine enamel erosions after soaking in chlorinated water. Southeast Asian J Trop Med Public Health. 2012; 43(5): 1292-6.

22. Walker GD, Cai F, Shen P, Bailey DL, Yuan Y, Cochrane NJ, Reynolds C, et al. Consumption Of Milk Added Casein Phosphopeptide Amorphous Calcium Phosphate Remineralizes Enamel Subsurface Lesions In Situ. Aust Dent J. 2009; 54(3): 245-49. DOI: 10.1111/j.18347819.2009.01127.x

23. Hajirostamloo B, Mahastie P. Comparison of Soy Milk and Cow Milk Nutritional parameter. Res J Biol Sci. 2008; 3(11): 1324-6. DOI: 10.ribsci.2008.1324.1326 